\title{
Role of community forest reserves in wildlife conservation in Benin, West Africa
}

\author{
Gaston S. AKOUEHOU ${ }^{1}$, Bruno A. DJOSSA ${ }^{2,3^{*}}$, F.C. AHONONGA ${ }^{1}$, \\ B.K. AWESSOU ${ }^{1}$ and B. A. SINSIN ${ }^{2}$ \\ ${ }^{1}$ Direction Générale des Forêts et des Ressources Naturelles (DGFRN / Bénin) \\ ${ }^{2}$ Laboratoire d'Ecologie Appliquée (LEA/FSA) \\ ${ }^{3}$ Ecole Nationale Supérieure des Sciences et Techniques Agronomiques (ENSTA) de Kétou \\ Corresponding author, E-mail: djossabruno@gmail.com
}

\begin{abstract}
Sacred groves and community forests are common ways for local rural African people to conserve natural resources. The importance of traditional approach in wildlife conservation was evaluated with line transect method utilized to assess five community forests. Comparable species richness with similar size protected forests of the same regions were reported. However, fauna composition in community forests was dominated by animals that can inhabit anthropogenic habitats like rodents, primates and small antelopes. We concluded the necessity to accompany such local initiatives mainly in regions lacking protected areas in order to give more chance to protect wildlife for present and future generation.
\end{abstract}

(c) 2010 International Formulae Group. All rights reserved.

Keywords: Community forest, wildlife, conservation, Benin.

\section{INTRODUCTION}

Habitat fragmentation and degradation is increasingly happening in tropics mainly in developing countries where the majority of the populations rely on natural resources (Djossa et al., 2008). The FAO's study conducted from 1990 to 1995 showed that the highest annual rate of African forest and woodland destruction occurred in West African countries such as Togo $(1,44 \%)$, Ghana $(1,26 \%)$, Benin $(1,25 \%)$ etc. (FAO, 1995). Benin has lost $6,990 \mathrm{~km}^{2}$ of forest within the period of 1990-2000, which corresponded to an annual deforestation rate of $2.3 \%$ (FAO, 2001). More recently, FAO (2005) reported an annually lost of 65000 ha for the same country. Benin is situated in the so called Dahomey Gap, a savanna corridor interrupting the zonal West African rain forest (Balloche et al., 2000; Salzmann and
Hoelzmann, 2005) reaching the coast of the Gulf of Guinea. Nowadays, this area is largely dominated by farms, fallows and grasslands intermingled with small fragments of rain forest (Adomou, 2005). Occupants of these areas were aware of this situation and "holy forest" attribution was since long the traditional way to prevent rare natural ecosystems from a rapid destruction. These habitats serve then to conserve natural resources and biodiversity (Sokpon and Agbo, 1999). In some area, community forests were preserved in a sort of consensus in the same goal. In general it is in the purpose to conserve rare plants and animals for traditional medicine or to preserve area for traditional rites and celebrations (Sokpon and Agbo, 1999; Liketa Shimbi, 2003; Kokou et al., 2005). As there is a lack of natural habitats, resident animals take these 
ecosystems as refuge. With a continuous anthropogenic pressure on natural ecosystems, wildlife is therefore restricted to protected areas. Any appropriate management action on wildlife needs accurate and detailed information on fauna diversity, abundance and spatial distribution (Seber, 1982; Wilson, 1994).

The present study aims to assess fauna diversity in 5 community forests distributed from the northern (Dahandé, Téfoungoun and Nonsinanson) to the central region (Zouzoukan and Fita-Agbado) of Benin, to appreciate the contribution of the traditional approach to the biodiversity conservation and to propose a flexible management method that permits a sustainable use of local resources.

\section{MATERIALS AND METHODS}

Study area

This study was carried out in

Zouzoukan, Fita-Agbado, Dahandé, Téfoungoun and Nonsinanson community forests.

Zouzoukan community forest is situated in Zou district and covers 36,119.07 ha laying between Zagnanado and Covè territories. It is geographically situated between $7^{\circ} 20^{\prime}-7^{\circ} 33^{\prime} \mathrm{N}$ and $2^{\circ} 11^{\prime}-2^{\circ} 22^{\prime} \mathrm{E}$. This forest is on a plateau of 200 to $300 \mathrm{~m}$ height; a sub equatorial climate with two dry and rain seasons. Annual mean rain fall is 985 $\mathrm{mm}$ distributed over 74 days of the year. Zou River is the important water course that carries water through this forest.

Fita-Agbado forest is located in Collines district and covers 36,885 ha laying between Dassa-Zoumè and Savalou territories $\left(7^{\circ} 34^{\prime}-7^{\circ} 50^{\prime} \mathrm{N}\right.$ and $\left.1^{\circ} 58^{\prime}-2^{\circ} 8^{\prime} \mathrm{E}\right)$. It is part of the climatic transition zone with only one dry and rain season, an annual mean rain fall reaching $1,100 \mathrm{~mm}$.

In the northern region of Benin, Nonsinanson $\left(9^{\circ} 23^{\prime}-9^{\circ} 44^{\prime} \mathrm{N}\right.$ and $2^{\circ} 40^{\prime}$ $\left.2^{\circ} 55^{\prime} \mathrm{E}\right)$ is located in Borgou district and covers 72,296 ha standing between N'Dali and Pèrèrè territories. The climate is sudanoguinean with one dry and rain season. Mean annual rain fall varies from 1,100 to 1,200 $\mathrm{mm}$ but can decline to $900 \mathrm{~mm}$. Okpara River is the important water course with its tributaries.

Téfoungou community forest $\left(9^{\circ} 27^{\prime}\right.$ $9^{\circ} 37^{\prime} \mathrm{N}$ and $\left.1^{\circ} 35^{\prime}-1^{\circ} 37^{\prime} \mathrm{E}\right)$ experiences a sudano-guinean climate type with annual mean rain fall varying from 1,200 to 1,300 $\mathrm{mm}$ and with one dry and rain season. This forest is located in Donga district, Djougou territory and covers $12,640.50$ ha.

Dahandé community forest $\left(10^{\circ} 26^{\prime}\right.$ $10^{\circ} 41^{\prime} \mathrm{N}$ and $\left.1^{\circ} 26^{\prime}-1^{\circ} 34^{\prime} \mathrm{E}\right)$ covers 30,379 ha, lays between Toukountouna, Tanguiéta and Natitingou territories in Atacora district. The climate is a relief influenced one with annual mean rain fall of $1,230 \mathrm{~mm}$ and with one dry and rain season (Figure 1).

\section{Survey design and transect installation}

We first visited the different community forests to recognize habitats' physiognomy and to track all important driveable roads with GPS that allowed defining the working shadow and document. The latter contained camping sites for sustainable use of time, transects positioning and walking azimuth and direction. During the visit, we had contact with villagers, local responsible and leaders in the different localities in order to negotiate and make arrangement and hire local people to make team with specialists for fieldwork. Transects were installed in homogenous habitats and were more or less perpendicular to water courses and to hilly terrains to avoid biases due to particular or potential concentration habitats.

In total, 49 transects were walked. Their lengths varied from 2 to $23 \mathrm{~km}$ and were separated by $2 \mathrm{~km}$ wide between the arriving point of one team and departing point of another team. The number and the length of transects depended on the size of each community forest. All together, $595 \mathrm{~km}$ were walked and the Nonsinason community forest, the largest one, took the highest proportion (226 out of $595 \mathrm{~km}$ ) (Table 1).

During the assessment period, vegetation coverage allowed the observer's vision to cover a strip of $100 \mathrm{~m}$ at each side of transect. Then, a total of $119 \mathrm{~km}^{2}$ was covered and represented $6.3 \%$ of all community forests together (Table 1).

\section{Survey techniques}

Wildlife assessment was done during the dry season (January $13-23^{\text {rd }}, 2010$ ) with line transect method (Buckland et al., 1993) that was suitable for areas where savannah was the dominate habitat type.

We formed 7 teams of 3 members each: team leader and 2 associated persons among which one native who knew well the areas and had a good skill in animal recognition. The team leader carried: a GPS that helped 
navigating from one point to another following transects and measured moving speed (about $4 \mathrm{~km} / \mathrm{h}$ ); a compass for orientation in order to walk along fix and predefined azimuth. He kept a data collection sheet on which different information were reported. These referred to the distance at which an animal was seen, the angle the detected animal was with the transect line, the animal's behaviour and/or activity, the habitat type. Additional variables were animal species, sex and age if possible, size of herd when they were in group. Everybody walked the same speed and parallel with transect. Transect walk started at 6:30 or 7:00 and finished at 16:00.

\section{Data analysis}

Collected data were compiled and the species richness was assessed. Density estimation with Distance 4.1 (Laake et al., 1994) software was not possible due to small size of animal-contacts data (less than 40) per community forest. We therefore calculated for each forest the Kilometric Abundance Index ( $\boldsymbol{I}_{\boldsymbol{k}}$ ) dividing the number of contacts (n) by total distance walked (d).

$$
\boldsymbol{I}_{\boldsymbol{k}}=\boldsymbol{n} / \boldsymbol{d}
$$

Based on this index, three classes of biodiversity were defined according to Gomsé and Mahop (2001) and Ahononga et al. (2008) as follows:

- $\quad$ area of lower fauna diversity when $I_{k}$ $<1$ animal $/ \mathrm{km}$;

- $\quad$ area of medium fauna diversity when $1 \leq I_{k}<2$ animals $/ \mathrm{km}$;

- $\quad$ area of high fauna diversity when $I_{k}$ $\geq 2$ animals $/ \mathrm{km}$.

We used presence-absence data to make classification in Statistica 6.0 and computed Jaccard's Index using Community Analysis Packages (CAP 2.15) to compare fauna composition among forests.

\section{RESULTS}

\section{Fauna diversity}

A total of 22 mammalian species distributed over 9 families and one snake species were reported in the 5 inventoried forests (Table 2).

Bovid species were the most represented (9 species), followed by rodents (4 species) that were fairly abundant in all surveyed community forest reserves and Civet was the rarest species.
A comparison of fauna diversity from surveyed community forests with similar size forests in same areas is presented on Figure 2.

Figures of species richness were similar when comparing community forests to protected forests of similar size from the same areas. Bovid and primate species were the most represented in the two regions both from community forests and protected forests. However, fauna community composition was different between community forests and protected forests.

A typology of habitats/forests was based on presence/absence data from surveyed community forests and selected protected forests from the same areas (Figure 3).

The topology of the dendrogram in Figure 3 showed a regional pattern even though protected forests were separated from community forests. In the northern region, Nonsinason was similar (Jaccards Index $I_{\mathrm{j}}$ ) with Téfoungou and Danhadé $\left(I_{j}=60 \%\right.$ and $76.9 \%$ respectively) community forests whereas Mékrou and N'dali protected forests were similar $\left(I_{j}=55.6 \%\right)$; in the central region Zounzoukan was similar with Fita-Agbado $\left(I_{j}\right.$ $=70.0 \%$ ) community forest.

\section{Fauna relative abundance}

Fauna abundance and diversity followed an overall similar pattern in these five studied community forests (Figure 4). Forests of central regions were more diverse and hosted more abundant fauna than northern region community forests.

\section{Kilometric abundance index $\left(\mathbf{I}_{\mathbf{k}}\right)$}

The number of contact with each animal species during the total walk transects was converted in number of contacts per 100 $\mathrm{km}$ (Table 3).

The two community forests of the central region showed the highest $\boldsymbol{I}_{\boldsymbol{k}}$ with the Crawshay's hare (Lepus crawshayi), the Bushbuck (Tragelaphus scriptus), the Grey (Common) duiker (Sylvicapra grimmia) and the Monticol's duiker (Cephalophus monticola). In this region, antelopes, rodents and primates contributed most to this abundance. Danhadé community forests (northern region) also presented overall good fauna relative abundance which antelopes, rodents and primates contributed to (Table 3 ).

According to the defined fauna diversity index, all community forests from the two different region displayed low fauna diversity $\left(\boldsymbol{I}_{\boldsymbol{k}}<1\right.$ animal $\left./ \mathrm{km}\right)$. 
Table 1: Prospecting effort.

\begin{tabular}{lccccc}
\hline $\mathbf{N}^{\circ}$ Transect & Fita-Agbagbo & Zounzoukan & Téfoungoun & Dahandé & Nonsinanson \\
\hline Transect 1 & 9 & 15 & 2 & 4 & 11 \\
Transect 2 & 10 & 17 & 5 & 7 & 16 \\
Transect 3 & 11 & 14 & 9 & 10 & 17 \\
Transect 4 & 16 & 14 & 9 & 14 & 18 \\
Transect 5 & 18 & 14 & 10 & 15 & 19 \\
Transect 6 & 16 & 9 & 9 & 15 & 20 \\
Transect 7 & 16 & 9 & - & 15 & 21 \\
Transect 8 & 14 & 8 & - & 7 & 15 \\
Transect 9 & 11 & 7 & - & 4 & 8 \\
Transect 10 & 6 & - & - & & 9 \\
Transect 11 & - & - & - & - & 15 \\
Transect 12 & - & - & - & - & 7 \\
Transect 13 & - & - & - & - & 20 \\
Transect 14 & - & - & - & - & 23 \\
Transect 15 & - & - & - & - & 7 \\
Total $(\mathrm{km})$ & 127 & 107 & 44 & 91 & 226 \\
\hline
\end{tabular}

\section{DISCUSSION}

Fauna diversity reported from the studied community forests were comparable with fauna diversity found in protected forests of the same region showing the importance of this traditional natural resources preservation in fauna conservation. Sacred groves in Ghana were found to be similar in plant species composition and structure to the deciduous forest of southern Ghana (Campbell, 2005). Between 1960 and 1996, these groves experienced far fewer forest losses than unprotected tree stands (less than 20\% as opposed to up to 100\%) (Campbell, 2005). Our findings were similar to fauna species richness reported by Sinsin (2004) from different protected forests in these regions and one rather common nocturnal carnivore, the Side stripped jackal (Canis adustus) was even recorded from three out of these five community forests. However, the fauna community composition reported from community forests is dominated by rodents and primates that can inhabit anthropogenic areas. Indeed, community forests are generally small sized so that large mammals necessitating large home ranges cannot be attached to such habitats as the risk to be hunted out is high.

The first pressure on fauna in tropic habitats and particularly in Africa is hunting, mainly for bush meat purposes ( $\mathrm{Fa}$ et al., 2005; Bassett, 2005). Commercial hunters, whose livelihoods depend entirely on the sale of wild animal meat, received the most attention of public and wildlife managers (Bassett, 2005) even though farmer hunters that dominate rural populations did not attract similar attention. For the wildlife utilization in Côte d'Ivoire $90 \%$ of hunters were farmers who hunt for both subsistence and commercial purposes (Caspary, 1999).

A study of the bushmeat trade in Ghana showed strong similarities with Côte d'Ivoire in terms of its organization and impact on wildlife populations (Mendelson et al., 2003; Cowlishaw et al., 2004). This is similar for Benin and for many other African countries. This situation persists despite hunting in this way was banned since long in all this countries. If community forest surveys still indicate such fauna diversity, one is right to believe that when conservation is decided upon consensus it shows a real effectiveness. 
Table 2: Censured species (contacts and tracks).

\begin{tabular}{|c|c|c|c|c|c|c|c|c|}
\hline Order & Family & Scientific name & Common name & Zounzoukan & Fita-Agbagbo & Nonsinason & Téfoungou & Dahandé \\
\hline \multirow{3}{*}{ Primates } & Cercopithecidae & Papio anubis & Olive Baboon & + & + & + & - & + \\
\hline & Cercopithecidae & Cercopithecus aethiops & Green monkey & + & + & - & - & - \\
\hline & Cercopithecidae & Erythrocebus patas & Patas or Red monkey & + & + & + & - & + \\
\hline \multirow{10}{*}{ Artiodactyls } & Bovidae & Alcelaphus buselaphus major & Western hartebeest & + & - & - & - & + \\
\hline & Bovidae & Ourebia ourebi & Ouribi & + & + & - & - & - \\
\hline & Bovidae & Syncerus caffer caffer & African Buffalo & + & - & - & - & + \\
\hline & Bovidae & Sylvicapra grimmia & Grey (Common) duiker & + & + & + & + & + \\
\hline & Bovidae & Cephalophus monticola & Monticol's duiker & - & + & - & - & - \\
\hline & Bovidae & Kobus ellipsyprimnus defassa & Defassa waterbuck & + & + & - & - & - \\
\hline & Bovidae & Tragelaphus scriptus & Bushbuck & + & + & + & - & + \\
\hline & Bovidae & Kobus kob & Western Buffon's kob & + & - & + & + & + \\
\hline & Bovidae & Cephalophus rufilatus & Red-flanked duiker & + & - & + & - & + \\
\hline & Suidae & Phacocheorus africanus & Common Warthog & + & + & - & - & - \\
\hline \multirow[b]{2}{*}{ Carnivores } & Viverridae & Civettictis civetta & African civet & + & - & - & - & - \\
\hline & Canidae & Canis adustus & Side stripped jackal & + & + & - & - & + \\
\hline \multirow{4}{*}{ Rodents } & Leporidae & Lepus crawshayi & Crawshay's hare & + & + & + & + & + \\
\hline & Cricetomydae & Cricetomys gambianus & Giant Gambian rat & + & + & + & + & + \\
\hline & Sciuridae & Euxerus erythropus & Stripped ground squirrel & + & + & + & + & + \\
\hline & Thryonomyidae & Thryonomys swinderianus & Grasscutter or can rat & + & + & + & + & + \\
\hline Reptiles & Boïdae & Python sebae & African rock python & + & + & - & - & - \\
\hline Total & & & & 19 & 15 & 10 & 6 & 13 \\
\hline
\end{tabular}


Table 3: Kilometric abundance of animal species in the studied community forests.

\begin{tabular}{lccccc}
\hline \multirow{2}{*}{ Species } & \multicolumn{5}{c}{ Kilometric abundance of species (individuals/100 km) } \\
\cline { 2 - 6 } & Dahandé & Téfoungou & Nonsinanson & Zounzoukan & Fita-Agbado \\
\hline Syncerus caffer caffer & 1 & - & - & - & - \\
Kobus ellipsyprimnus defassa & 1 & - & - & - & - \\
Kobus kob kob & 1 & - & - & 1 & - \\
Alcelaphus buselaphus major & 5 & - & - & - & \\
Tragelaphus scriptus & 3 & 2 & 2 & 15 & 4 \\
Ourebia ourebi & 2 & - & - & - & - \\
Sylvicapra grimmia & 4 & 2 & 1 & 15 & 6 \\
Cephalophus monticola & - & - & - & 4 & 12 \\
Cephalophus rufilatus & - & - & - & - & 7 \\
Canis adustus & 1 & - & - & - & - \\
Civettictis civetta & - & - & - & 1 & 2 \\
Phacocheorus africanus & - & - & - & - & 2 \\
Cercopithecus aethiops & - & - & - & 2 & 3 \\
Papio anubis & 3 & - & - & & - \\
Erythrocebus patas & 1 & - & - & 2 & 3 \\
Cricetomys gambianus & 1 & - & - & & - \\
Xerus erythropus & 1 & - & - & 4 & 2 \\
Thyonomys swinderianus & 7 & - & 2 & 7 & 5 \\
Lepus crawshayi & 1 & 5 & 1 & 2 & 45 \\
\hline
\end{tabular}

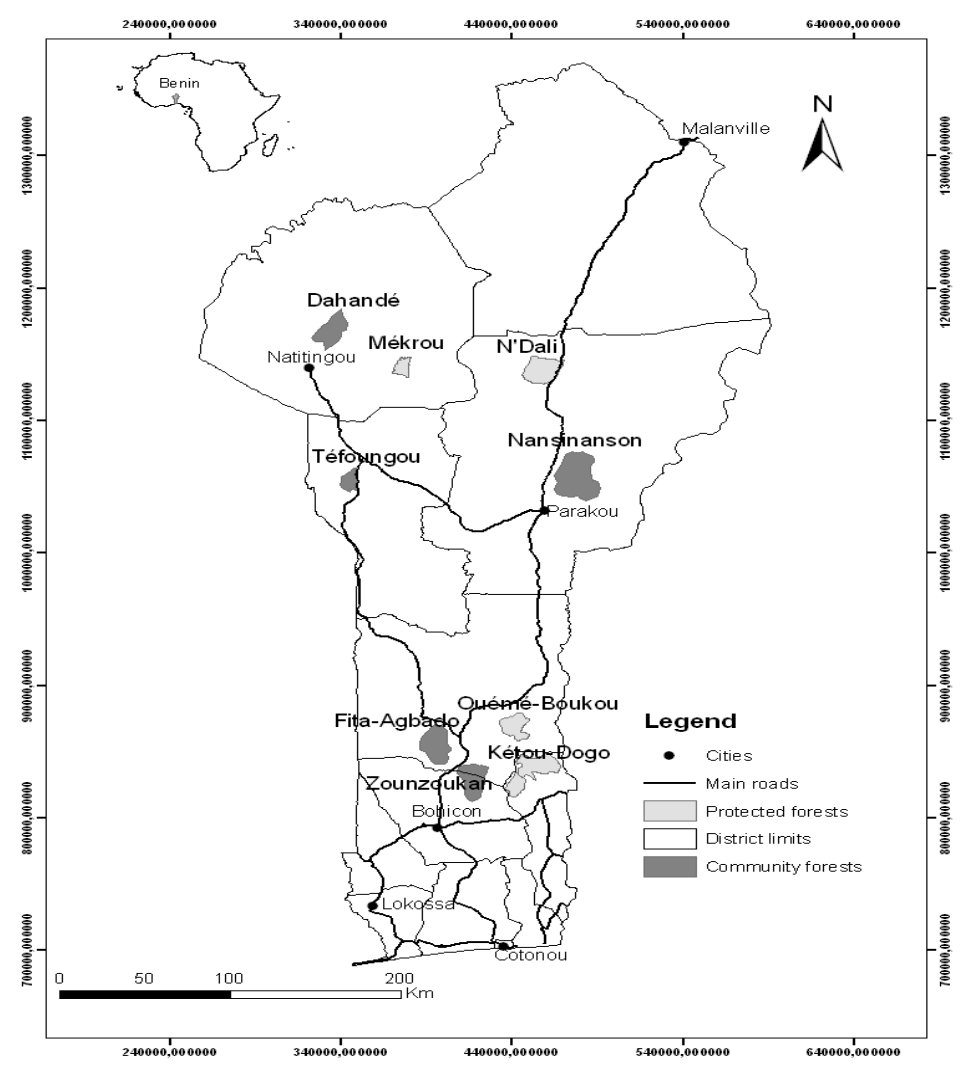

Figure 1: Benin map with the situation of the 5 different community forests (dark) and two similar size protected forests (grey) from each region. 

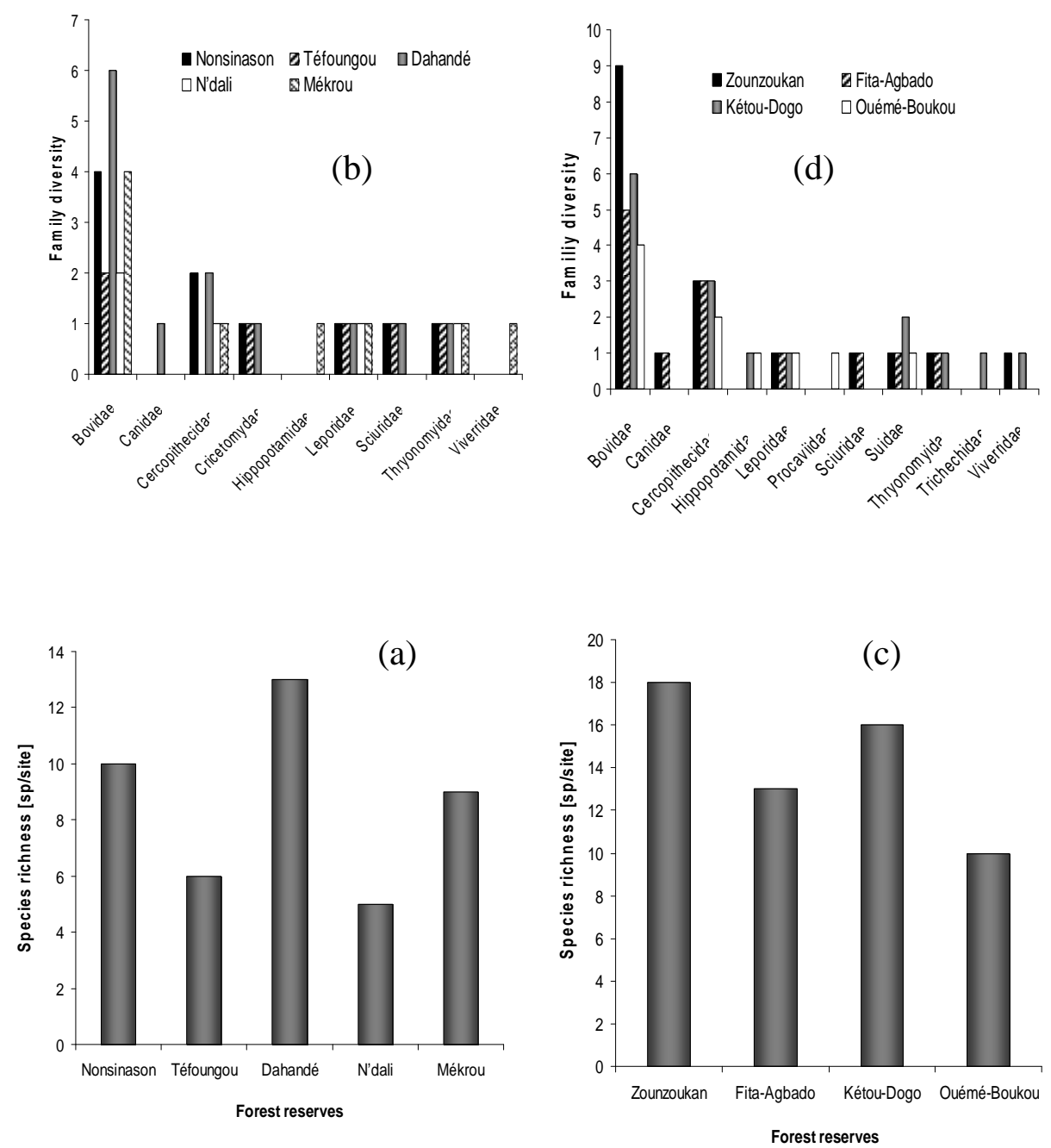

Figure 2: Species richness of surveyed community forests compared with similar size forests from the same areas. Nonsinason, Téfoungou and Danhadé community forests compared with N'dali and Mékrou forest reserves (a \& b) in the northern region; Zounzounkan and Fita-Agbado community forests compared with Kétou-Dogo and Ouéme-Boukou (c \& d) in the central region of Benin.

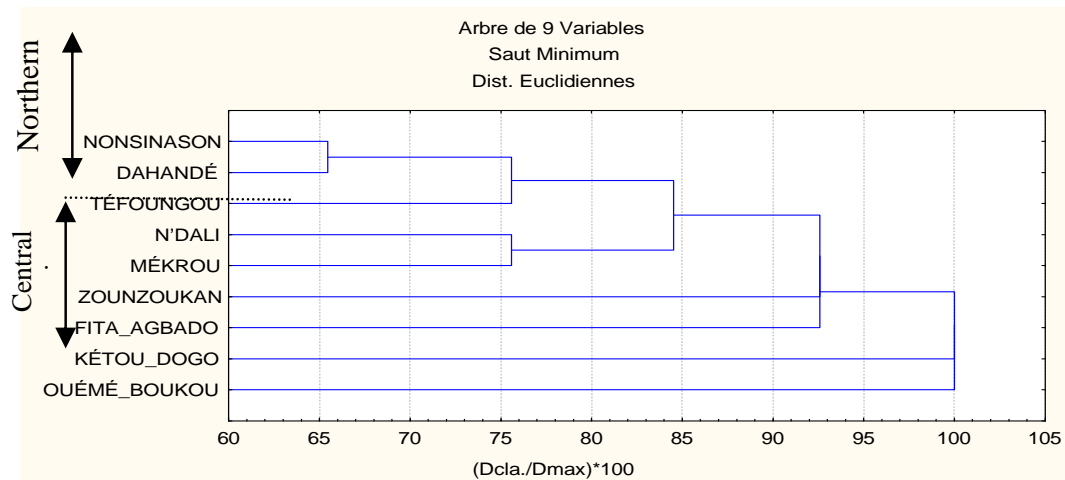

Figure 3: Classification of habitats based on presence-absence of fauna species. 


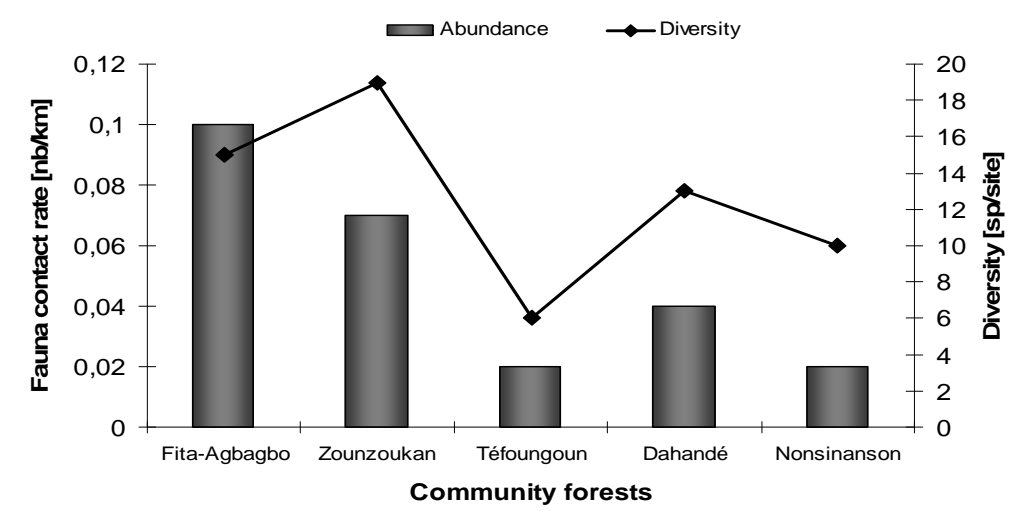

Figure 4: Fauna abundance compared with diversity in studied community forests.

Although some supporting cultures have been weakened by modern influences, sacred groves are frequently more acceptable to local peoples than externally imposed conservation policies in Ghana (Ntiamoa-Baidu, 1994) and in Benin (Sokpon and Agbo, 1999). Moreover, community based conservation shows good effectiveness when it is built on benefits sharing (Kiss, 2004). Many of legally protected forests were and still being disturbed and their fauna population being depleted despite all efforts from wildlife managers. Participatory management approach is nowadays promoted (Alexander, 2000; Lambin et al., 2001) as it came out that force control on natural resources conservation showed its limits. Fita-Agbado and Zounzounka showed the highest contact rates during survey period. Small sized antelopes and rodents are the most represented animals whereas Dahandé that showed lower contact rates still hosting large sized antelopes and rodents as well demonstrating a certain ecological value that can be ranked higher than what were reported from these two first community forests. Anthropogenic pressure in northern and central region of Benin is mainly due to agro pastoral activities (Houinato and Sinsin, 2000). The northern community forests that showed lower contact rates faced transhumance pressure that decreases from North toward South parts of the country.

Deforestation and habitat fragmentation are known to modify fauna community composition as reported in bat fauna by Brosset et al. (1996) from French Guyana because diverse habitat is a guaranty for high diversity in this small mammals group (Fahr et al., 2006). Community forest is supposed to experience a certain exploitation of natural resources by local human populations and this coexistence or conflict between human and animals inhabiting this forest are with certainty detrimental to non opportunistic fauna. Non timber forest product harvest can affect fruit eating mammals (Moegenburg and Levey, 2003). The importance of protected areas in biodiversity conservation shows that in a situation of absence of parks and forest reserves, community forests play similar role with relative effectiveness (Bruner et al., 2001). Small sized forests are also unlikely to maintain large sized mammals such as big antelopes because the diversity of habitat used has a strong link with the body live weight for ruminant browsers (Du Toit and Owen-Smith, 1989). This seems to hold true in the context of the present study where big antelopes were not common compared with small sized ones.

Anyhow, community forest surveys prove their importance in fauna conservation and merit to be considered in natural resources management plans in Benin, mainly where protected areas or National Parks are lacking like the southern region of the country. There is of course a need of corridors to connect them so that such network of community forests will provide somehow large habitat for the wildlife. It is also interesting to "copy" local approach and working ambiance leading to conserving these community forests and to apply as far as possible when deciding the 
participatory approach in the management of legally protected forests whose prescriptions are very often not respected by human communities living around. It is obvious that sacred groves and community forests cannot be ignored anymore in conservation strategies definition so that the necessity to make some changes in laws related to natural resources protection is an urgent need; thereby, giving more chances to conserve resources for current and future generations.

\section{ACKNOWLEDGMENTS}

We acknowledge important support from local people for field assistance and guidance, local authorities for granting research permit and the Project for Firewood whose acronym is PBF 2 (French: Projet Bois de Feu 2) for financial support of this study.

\section{REFERENCES}

Adomou AC. 2005. Vegetation patterns and environmental gradients in Bénin: Implications for biogeography and conservation. PhD-Thesis, University of Wageningen, p.136.

Ahononga FC. 2008. Impacts des régimes de gestion de la faune sur le distribution des carnivores dans le parc National de Bouba-N'djida et la Zone cynégétique 11. Mémoire de fin d'étude, Universités de Dschang (Cameroun) et de Leyden (Pays bas), p. 55.

Alexander SE. 2000. Resident attitudes towards conservation and black howler monkeys in Belize: the Community Baboon Sanctuary. Environment Conservation, 27: 341-350.

Ballouche A, Akoègninou A, Neumann K, Salzmann U and Sowunmi A. 2000. Le Projet "Dahomey Gap": une contribution à l'histoire de la végétation du Sud-Bénin et du Sud-Ouest du Nigeria. Berichte des Sonderforschungsbereichs 268, Band 14, Frankfurt A.M; 237-251.

Bassett TJ. 2005. Card-carrying hunters, rural poverty, and wildlife decline in northern Côte d'Ivoire. The Geographical Journal, 171(1): 24-35.

Brosset A, Charles-Dominique P, Cockle A, Cosson J-F, Masson D. 1996. Bat communities and deforestation in French Guiana. Can. J. Zool., 74(11): 1974-1982.
Buckland DST, Anderson DR, Burnham KP, Laake JL. 1993. Distance Sampling. Estimating Abundance of Biological Populations. Chapman et Hall; 446.

Bruner AG, Gullison RE, Rice RE, Da Fonseca GAB. 2001. Effectiveness of parks in protecting tropical biodiversity. Science, 291: 125-128.

Campbell MO. 2005. Traditional forest protection and woodlots in the coastal savannah of Ghana. Environmental Conservation, 31(3): 225-232.

Caspary H-U. 1999. Utilisation de la faune sauvage en Côte d'Ivoire et Afrique de l'Ouest -potentiels et contraintes pour la coopération au développement GTZ, Eschborn.

Cowlishaw G, Mendelson S, Rowcliffe JM. 2004. The bushmeat commodity chain: patterns of trade and sustainability in a mature urban market in West Africa ODI Wildlife Policy Briefing 7.

Djossa BA, Fahr J, Wiegand T, Ayihouénou BE, Kalko EKV, Sinsin BA. 2008. Land use impact on Vitellaria paradoxa C.F. Gaerten. Stand structure and distribution patterns: a comparison of Biosphere Reserve of Pendjari in Atacora district in Benin. Agroforestry Syst., 72: 205-220.

Du Toit JT, Owen-Smith N. 1989. Body size, population metabolism and habitat specialisation among large African herbivores. American Naturalist, 133: 736-740.

Fa JE, Ryan SF, Bell DJ. 2005. Hunting vulnerability, ecological characteristics and harvest rates of bushmeat species in Afrotropical forests. Biological Conservation, 121: 167-176.

Fahr J, Djossa BA, Vierhaus H. 2006. Rapid assessment of bats (Chiroptera) in Déré, Diécké and Mt. Béro classified forests, Southeastern Guinea; including a review of the distribution of bats in Guinée Forestière. In A Rapid Biological Assessment of Three Classified Forests in Southeastern Guinea, Wright HE, McCullough J, Alonso LE Diallo MS (eds). RAP Bulletin of Biological Assessment $40 . \quad$ Conservation International, Washington, DC; 69-81.

FAO. 1995. Forest resources assessment 1990 - Global synthesis. FAO Forestry Paper 124. 
FAO. 2001. Global Forest Resource Assessment 2000: Main Report. FAO, Rome.

FAO. 2005. Evaluation des Ressources Forestières Mondiales 2005. FAO. Rome. Italie. 320pp

Gomsé A, Mahop JP. 2001. Dénombrement de grands mammifères dans le Parc national de Bouba N'Djidda. Rapport d'étude, WWF/PSSN, 46 p.

Houinato M, Sinsin B. 2000. La pression Agro-pastorale sur la zone riveraine de la Réserve de Biosphère de la Pendjari. Tropicultura, 18(3): 112-117.

Kiss A. 2004. Is community-based ecotourism a good use of biodiversity conservation funds? Trends in Ecology and Evolution, 19(5): 232-237.

Kokou K, Adjossou K, Hamberger K. 2005. Les forêts sacrées de l'aire Ouatchi au sud-est du Togo et les contraintes actuelles des modes de gestion locale des ressources forestières. Revues en Sciences de l'Environnement Vertigo, 6(3): 11.

Laake JL, Buckland ST, Anderson DR, Burnham KP. 1994. Distance user's guide V2.2. Colorado Cooperative Fish and Wildlife Research Unit, Colorado State University, Fort Collins.

Lambin EF, Turner BL, Geist HJ, Agbola SB, Angelsen A, Bruce JW, Coomes OT, Drizo R, Fischer G, Folke C, George PS, Homewood K, Imbernon J, Leemens R, Xiubin L, Moran EF, Mortimore M, Ramakrishnan PS, Richards JF, Skanes H, Steffen W, Stone GD, Svedin U, Velkamp TA, Vogel C, Xu J. 2001. The causes of land-use and land cover change: moving beyond the myths. Global Environmental Change, 11(4): 261-269.

Luketa SH. 2003. Forêts sacrées et conservation de la biodiversité en Afrique centrale: cas de la République démocratique du Congo. Mémoire soumis au XIIe congrès forestier mondial, Québec City, Canada, 10p.

Mendelson S, Cowlishaw G, Rowcliffe JM. 2003. Anatomy of a bushmeat commodity chain in Takoradi, Ghana. Journal of Peasant Studies, 31: 73-100

Moegenburg SM, Levey DJ. 2003. Do frugivores respond to fruit harvest? An experimental study of short-term responses. Ecology, 84(10): 2600-2612.

Ntiamoa-Baidu B. 1994. Indigenous versus traditional biodiversity conservation strategies: the case of protected area systems. In African Biodiversity: Foundation for the Future: Framework for Integrating Biodiversity Conservation and Sustainable Development. USAID: Washington DC, USA; 66-67.

Salzmann U, Hoelzmann P. 2005. The Dahomey Gap: An abrupt climatically induced rain forest fragmentation in West Africa during the late Holocene. The Holocene, 15(2): 190-199.

Seber G. 1982. The Estimation of Animal Abundance and Related Parameters $\left(2^{\text {nd }}\right.$ edn). Charles Griffin: London.

Sinsin B. 2004. Evaluation de la diversité biologique des zones d'intervention du Programme de Gestion et terroirs Riverains. Rapport de synthèse, p. 77.

Sokpon N, Agbo V. 1999. Sacred groves as tools for indigenous forest management in Benin. Annales des Sciences Agronomiques, Université Nationale $d u$ Bénin, 1: 162 - 175.

Wilson EO. 1994. Stratégie pour la conservation de la biodiversité. Rapport WRI, UICN, PNUE Gland, Suisse 21 40p. 